Signs of the Times 
This page intentionally left blank 


\title{
Signs of the Times
}

The Visual Politics of Jim Crow

\author{
Elizabeth Abel
}

\section{뚜}

UNIVERSITY OF CALIFORNIA PRESS

Berkeley Los Angeles London 
University of California Press, one of the most distinguished university presses in the United States, enriches lives around the world by advancing scholarship in the humanities, social sciences, and natural sciences. Its activities are supported by the UC Press Foundation and by philanthropic contributions from individuals and institutions. For more information, visit www.ucpress.edu.

University of California Press

Berkeley and Los Angeles, California

University of California Press, Ltd.

London, England

(C) 2010 by The Regents of the University of California

Library of Congress Cataloging-in-Publication Data

Abel, Elizabeth.

Signs of the times : the visual politics of Jim Crow / Elizabeth Abel.

p. $\mathrm{cm}$.

Includes bibliographical references and index.

ISBN 978-0-520-26117-4 (cloth : alk. paper)

ISBN 978-0-520-26183-9 (pbk. : alk. paper)

1. African Americans-Segregation-Southern States-History2oth century. 2. Visual communication-Southern States-History2oth century. 3. Signs and signboards-Southern States-History2oth century. 4. Photography-Social aspects-Southern StatesHistory-2oth century. 5. Racism in popular culture-Southern StatesHistory-2oth century. 6. Southern States-Race relations-History2oth century. I. Title.

E185.61.A164 2010

$305.800975-\mathrm{dc} 22$ 2009020570

Manufactured in the United States of America

$\begin{array}{llllllllll}19 & 18 & 17 & 16 & 15 & 14 & 13 & 12 & 11 & 10\end{array}$

$\begin{array}{llllllllll}10 & 9 & 8 & 7 & 6 & 5 & 4 & 3 & 2 & 1\end{array}$

The paper used in this publication meets the minimum requirements of ANSI/Niso Z39.48-1992 (R 1997) (Permanence of Paper). 
For Richard Meyer and Benjamin Abel Meyer, with love 
This page intentionally left blank 